\title{
PEMBARUAN ISLAM BIDANG KELUARGA : RELEVANSI DAN SOLUSI TERHADAP PERSOALAN NUSYUZ
}

\author{
Hulaimi Azhari1 ${ }^{1}$ Ninda Ayu Nafisah ${ }^{2}$ \\ ${ }^{1}$ Universitas Islam Negeri Sunan Kalijaga Yogyakarta \\ Email: hulaimiazhari39@gmail.com \\ Universitas Islam Negeri Sunan Kalijaga Yogyakarta \\ Email: nindaayunafisah@gmail.com
}

\begin{abstract}
Before the arrival of Islam, Arab society was a society that was far from being orderly and according to norms. Customs, morals and life rules adopted are habits that have existed for a long time and are adopted as habits and beliefs. In a society that is oriented towards human values, Islam comes with a concept that forms the order of pre-Islamic Arab society in a relatively precise manner. Islam as a religion changes several aspects of society, one of which is in the family. One of the discussions in the family field is the remaining settlement of nusyuz in Islam where nusyuz is a disobedient attitude between husband or wife. This type of writing is a literature study, namely a study in which data collection is obtained from various scientific literacy such as books, journals, articles and others. The data of this study consisted of secondary and primary data with qualitative methods. The findings resulted that the offer of another Qur'an was first, offering advice to the wife in a ma'ruf or good way which aims to awaken the wife from her wrong actions. Second, as a psychological punishment for the wife and in her solitude for committing a crime against her punishment. Third, giving physical punishment to the wife.
\end{abstract}

Keywords: Islamic Renewal, Relevance, Nusyuz

\begin{abstract}
Abstrak
Sebelum kedatangan Islam, masyarakat Arab merupakan masyarakat yang jauh dari kata teratur dan sesuai norma. Adat istiadat, akhlak serta peraturan hidup yang dianut merupakan kebiasaan yang telah ada sejak dahulu dan dianut sebagai kebiasaan dan keyakinan. Dalam suatu masyarakat yang cenderung mengabaikan nilai-nilai kemanusiaan, agama Islam datang dengan konsep pembaruan yang merubah tatanan masyarakat Arab pra-Islam dalam waktu yang relatif cukup simgkat. Islam sebagai agama pembaruan merubah beberapa aspek yang ada dalam masyarakat, salah satunya ialah dalam bidang keluarga. Salah satu yang menjadi pembahasan dalam bidang keluarga ialah penyelesaian nusyuz dalam Islam dimana nusyuz merupakan sikap tidak patuh antara suami atau istri. Tulisan ini berjenis kajian library research yakni sebuah kajian yang pengambilan datanya didapat dari pelbagai literasi ilmiah seperti buku, jurnal, artikel dan
\end{abstract}


lainnya. Adapun data penelitian ini terdiri atas data sekunder dan primer dengan metode kualitatif. Temuan yang dihasilkan bahwasanya tawaran al-Qur'an lain Pertama, pemberian nasihat kepada istri dengan cara yang ma'ruf atau baik yang bertujuan untuk menyadarkan istri dari perbuatannya yang keliru. Kedua, sebagai hukuman psikologis bagi istri dan dalam kesendiriannya unutuk melakukan koreksi terhadap kekeliruannya. Ketiga, memberikan hukuman fisik kepada istri.

Kata Kunci: Pembaruan Islam, Relevansi, Nusyuz

\section{A. Pendahuluan}

Kedatangan Islam dan pembawanya, Muhammad S.A.W di tengah masyarakat Arab sungguh merupakan suatu reformasi yang besar. Dalam suatu masyarakat yang cenderung mengabaikan nilai-nilai kemanusiaan, Agama Islam datang dengan ketentuan yang tertera dalam al-Qur'an dan hadits nabi mampu merubahnya dalam waktu yang relatif singkat. Pada masa pra-Islam masyarakat Arab biasa disebut dengan masyarakat jahiliyah merupakan komunitas yang mengabaikan atau mengingkari fitrah manusia. Cara hidup yang sering atau lazim dijumpai di kalangan masyarakat jahiliyah ialah mereka menyukai minuman khamar, mereka juga memiliki fanatisme kesukuan yang tinggi, dan penempatan kaum perempuan pada derajat yang rendah.

Masudul Hasan menggambarkan keadaan tersebut dengan memberikan pernyataan sebagai berikut:

Kecendrungan banyak orang mengonsumsi minum-minuman yang keras, perjudian, melakukan pencabulan, meraja lelanya seks serta merosotnya sebuah moral. Kaum wanita bagaikan suatu barang-barang yang mudah diperjualbelikan. Jika meninggalnya seseorang, maka maka sang ibu tiri akan diwarisi oleh anaknya bersama suatu barang serta bisa menikahi mereka, merupakan hal yang memalukan disaat seseorang melahirkan seorang anak perempuan. Merupakan sesuatu kewajaran dalam hal perbudakan serta hal terkait hidup matinya seorang budak merupakan hak milik serta kuasa seorang tuan. Adapun yang menjadi sajian disetiap harinya ialah sesuatu yang berbau keribaan, orang-orang yang miskin dan yang membutuhkan akan tereksploitasikan oleh orang-orang yang 
berharta. Hadirnya jurang pemisah antara orang-orang miskin dan orang-orang berharta". ${ }^{1}$

Kondisi masyarakat yang demikian tentunya tidak dapat dikatakan sebagai masyarakat yang ideal. Apabila melihat kepada kebiasaan dan pola hidup masyarakat jahiliyah dapat disimpulkan bahwa pola hidup masyarakatnya mercerminkan masyarakat yang masih belum beradab.

Agama Islam datang dengan ketentuan yang tertera dalam al-Qur'an dan hadits nabi sebagai pembawa perubahan. Dalam waktu yang relatif singkat, Islam merubah cara pola hidup dari masyarakat yang biadab menjadi masyarakat yang beradab. Menarik untuk dicermati, kedatangan Islam tidak semena-mena merombak nilai-nilai yang dianut masyarakat secara keseluruhan. Artinya, Islam tidak mengikis habis nilai-nilai kemuliaan dalam pandangan mereka dan menggantinya dengan nilai-nilai yang sama sekali baru akan tetapi Islam mengakomodir nilai-nilai itu dan mengarahkannya kepada hal yang sesuai dengan syariat. Nilai-nilai seperti kemuliaan, kedermawanan, dan keberanian yang dianggap baik oleh bangsa Arab tetap dipertahankan dan diubah cara serta tujuannya. ${ }^{2}$

Kedermawanan yang sebelumnya diartikan sebagai penghamburan harta yang sia-sia kini diganti sebagai pemberian harta kepada fakir miskin yang membutuhkan. Keberanian yang sebelumnya ditujukan untuk membela kehormatan diri dan suku kemudian diganti dengan pembelaan kepada agama. Demikianlah masyarakat Arab mengalami perubahan hidup yang besar. Dari masa jahiliyah menuju masa Islam.

Masyarakat Arab pra-Islam atau sebelum datangnya Islam sering disebut dengan masyarakat Jahiliyah yang secara bahasa memiliki makna yakni kebodohan atau tidak tahu. ${ }^{3}$ Arti kata kebodohan disini bukanlah menerangkan bahwa masyarakat yang hidup pada masa itu adalah

\footnotetext{
${ }^{1}$ Masudul Hasan, History of Islam, Vol. 1, (India: Adam Published, 1995), 48.

2 Zakaria Bashier, The Makkan Crucible, (Licester: Islamic Foundation, 1978), 27.

${ }^{3}$ Ali dan Ahmad Zuhdi, Kamus Kontemporer, (Yogya: Yayasan Ali Maksum, 1996), 648.
} 
masyarakat yang bodoh melainkan makna yang sesungguhnya ialah masyarakat yang hidup pada saat itu memiliki pola hidup yang negatif, kesombongan yang ditonjolkan, kemarahan dalam penyelesaian masalah dan ketidaktahuan akan suatu hal yang mendarah daging. ${ }^{4}$

Ajaran-ajaran yang terdapat dalam agama Islam atau pembaruan Islam yang datang memiliki tujuan untuk mengubah adat-adat, ide-ide, dan kerusakan moral yang ada dalam masyarakat pra-Islam atau masyarakat jahiliyah pada masa itu. Sistem hukum yang telah menjadi kebiasaan pada masa itu dirombak bahkan diganti dengan sistem hukum yang baru yaitu sistem hukum Islam.

Islam datang sebagai agama permbaruan merubah bebrapa aspek kehidupan masayarakat jahiliyah. Jika dikelompokkan beberapa pembaruan yang dibawa oleh islam antara lain: ${ }^{5}$

1) Islam mengubah sistem kekeluargaan yang dianut masyarakat Jahiliyah, dimana mereka mengutamakan kaum laki-laki diatas kaum perempuan (patriarkal) menjadi masyarakat yang memberi kesetaraan antara lakilaki dan perempuan

2) Sistem kepercayaan atau keyakinan yang diantu berubah dari politeis mengakui anyak tuhan diperbarui menjadi sistem monoteis yang hanya mengakui tuhan yang esa.

3) Sistem sosial yang sebelumnya hierarkis berstruktur menjaid ekonomi yang berkeadilan.

4) Sistem ekonomi yang sebelumnya borjuis kapitalis berubah menjadi sistem ekonomi berkeadilan.

5) Sistem tanggung-jawab kolektif berubah menjadi sistem tanggung jawab individu, dan

\footnotetext{
${ }^{4}$ Hasan Ibrahim Hasan, Tarikh al- Islam, Vol. 1, (Beirut: Dar al- Jayl, 1996), 66.

5 Khoiruddin Nasution, "Islam Membangun Masyarakat Bilateral dan Implikasinya terhadap Hukum Keluarga Islam Indonesia”, dalam Jurnal al-Mawarid, Edisi xvii, (2007), 8586.
} 
6) Dasar hubungan antara individu satu dengan lainnya, dari status sosial dan kelompok menjadi ikatan agama (iman).

Salah satu pembaruan yang dilakukan oleh agama Islam ialah pembaruan di bidang hukum keluarga. Hukum keluarga sendiri termasuk dalam sistem kekeluargaan dan sistem sosial yang diperbarui pada masa jahiliyah. Masalah-masalah yang terkait dengan hukum keluarga telah mengalami perombakan secara bertahap atau berangsur-angsur, hal ini dibuktikan dengan adanya nash di bidang hukum keluarga yang masih bersifat patriarkal yang memang harus ditinjau dan dikaji secara mendalam terkait dengan perkembangan zaman dan demi menuju kemashlahatan.

Salah satu pembahasan yang dibahas dalam bidang keluarga ialah permasalahan nusyuz dalam rumah tangga. Nusyuz yang identik dengan pembangkangan atau tidak patuhnya antara suami atau isteri menjadi pembahasan tersendiri dalam konsep hukum keluarga. Dalam pembahasan terkait nusyuz dalam rumah tangga, terdapat pembahasan terkait penyelesaian dari nusyuz. Proses penyelesaian dari nusyuz tidak terlepas dari beberapa opsi atau pilihan langkah-langkah yang diambil dari seorang suami dalam rangka menyadarkan isteri dari sikap membangkang atau tidak patuh. ${ }^{6}$

Islam yang datang sebagai agama pembaruan bagi masyarakat jahiliyah jelas membawa perubahan terhadap pemahaman atau konsep terkait dengan hukum keluarga. Hal ini tidak terlepas juga dari pembahasan penyelesaian nusyuz pada masa pra-Islam dengan konsep setelah datangnya Islam. Pada pembahasan kali ini penulis mencoba untuk mengkaji lebih dalam terkait dengan pembaruan Islam di bidang keluarga serta relevansi dan solusi atas problematika nusyuz diantara pasangan suami istri. Bagaimana perbedaan konsep penyelesaian nusyuz antara

\footnotetext{
${ }^{6}$ Ali Yusuf as-Subki, Fiqh Keluarga, (Jakarta: Amzah, 2010), 302.
} 
keduanya dan relevansi terkait dengan pembaruan Islam di bidang keluarga akan dibahas secara mendalam.

\section{B. Pembahasan}

\section{Masyarakat Arab pra-Islam}

Peradaban Arab pra Islam sering pula dikenal dengan nama Era Jahiliyyah (kebodohan). Penamaan ini bukan semata-mata karena kebodohan mereka dalam berbagai aspek, namun penamaan ini disematkan karena ketiadaan pengetahuan mereka akan agama, sosial kemasyarakatan, politik, dan pengetahuan tentang ke-Esaan Allah. Disamping faktor teologis tersebut, mereka memiliki beberapa karakteristik khusus yang semakin memperkuat kesan Jahil (bodoh) pada mereka. ${ }^{7}$ Lebih jauh, Ignaz Goldziher, seorang orientalis asal Hongaria menjelaskan bahwa kondisi masyarakat kala itu bukan hanya jahiliyyah, namun juga barbarisme dan cenderung primitif.

Diantara ciri khas keburukan yang melekat pada masyarakat Arab praIslam ialah mereka menganggap rendah kaum wanita dan menjunjung tingga derajat kaum laki-laki sebagai superior di kalangan mereka. Mereka menganggap kaum wanita begitu rendah, bahkan dianggap sebagai barang dan hewan ternak yang tidak memiliki hak. Mereka juga tidka dapat menjadi pewaris dari suami atau orang tuanya, para lelaki bebas untuk menikah dengan wanita berapapun jumlahnya, sedangkan tidak demikian bagi wanita. ${ }^{8}$

Kondisi perempuan pada masa jahiliyyah digambarkan dalam alQur'an surat al-Nahl ayat 58-59 sebagai berikut:

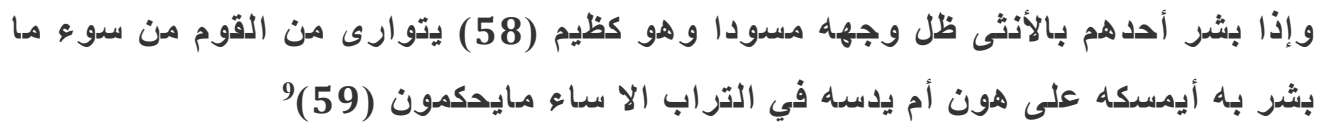

Ayat diatas menjelaskan tentang sikap masyarakat jahiliyah terhadap kelahiran anak perempuan yang dianggap sangat memalukan bagi mereka.

${ }^{7}$ Dedi Supriyadi, Sejarah Peradaan Islam, cet. VIII, (Bandung: Pustaka Setia, 2016), 57.

8 Ibid., 55.

${ }^{9}$ Al-Nahl (16): 58-59. 
Kelahiran anak perempuan dianggap sebagai aib bagi orang tua dan keluarga, sehingga tidak jarang dari mereka membunuh anak perempuan tersebut bahkan ada yang langsung menguburnya hidup-hidup ketika masih bayi. Perlakuan tidak adil dan pelabelan perempuan sebagai simbol kenistaan merupakan karakter yang melekat kuat pada masyarakat jahiliyah. ${ }^{10}$

Bangsa Arab terdahulu dikenal sebagai bangsa yang hidup dalam kelompok-kelompok, mereka hidup berdampingan antara satu kelompok dengan kelompok yang lain. Kecintaan mereka erhadap kelompok, keluarga, garis keturunan (nasab) mengalahkan kecintaan mereka dengan hal lain. Sifat seperti ini dikenal sebagai sifat rasial yang dimiliki oleh masyarakat Jahiliyah. Hal ini ditunjukan dengan adanya perasaan berlebihan (ultra nasionalisme) dan kesukuan serta pembelaan terhadap orang-orang yang ada di dalamnya atau satu suku dengannya. Ibn Khaldun menyebutnya dengan istilah al'Ashabiyah. ${ }^{11}$

Bentuk pemerintahan yang dianut oleh masyarakat Jahiliyah pada kala itu ialah bentuk pemerintahan oligarki dimana pemerintahan dilaksanakan oleh suatu kelompok atau beberapa ornag yang membagi kekuasaan dalam bidang masing-masing dan bidang-bidang tertentu. Terdapat kelompok atau kabilah yang menangani masalah peribadatan, terdapat pula kelompok atau kabilah yang menangani masalah ekonomu dan pertahanan. ${ }^{12}$

Melihat pada segi teologisnya, masyarakat arab pada masa pra-Islam telah mengenal beberapa agama seperti paganisme, Kristen, Yahudi, dan Majusi. Budaya paganisme terasa lebih kental dalam bangsa Arab pra-Islam dengan banyaknya patung-patung yang disembah dan diletakkan disekitar Ka'bah sebagai manifestasi tuhan-tuhan sembahan mereka. Sedikitnya

${ }^{10}$ Haifa Jawad, The Right of Women in Islam; An Authentic Approach, Cet I, (New York: S.T. Martin's Press, 1989), 1-3.

11 Yuangga Kurnia Yahya, "Pengaruh Penyebaran Islam di Timur Tengah dan Afrika Utara: Studi Geobdaya dan Geopolitik”, dalam Jurnal al-Tsaqafa, Vol. 16, No. 1, (2019), 47.

12 M. Abdul Karim, Sejarah Pemikiran dan Peradaban Islam, Cet. VI, (Yogyakarta: Bagasakara, 2015), 55. 
terdapat 360 buah patung disekeliling Ka'bah yang mewakili tiap-tiap kabilah dan suku tertentu. ${ }^{13}$ Mereka menamai patung-patung yang mereka buat dengan nama-nama khusus dimana dengan itu mereka mamanjantak doa dan meminta dihindarkan dari segala mara bahaya.

Karakter lain yang cukup menonjol dari masyarakat Jahiliyah ialah karater feudal dimana kaum kaya atau bangsawan memiliki superioritas diatas kaum miskin dan lemah. Mata pencaharian mayoritas masyarakat Jahiliyah pada saat itu ialah berdagang, dimana mereka sangat mengutamakan kesejahteraan materi diatas segalanya. Kaum kaya yang memang lebih sukses dari hasil berdagang menjadi pemegang kekuasaan dan sekaligus menjadi golongan yang makmur dan sejahtera, hal ini berlaku sebaliknya pada kaum miskin yang semakin lemah dan semakin tertindas dengan karakter feudal yang dianut oleh masyarakat Jahiliyah.

Penjabaran terkait dengan sifat dan karakter masyarakat pra-Islam diatas sudah mencerminkan bahwa kehidupan masyarakat arab pra-Islam dahulu tidak teratur dan tidak beradab. Penyimpangan yang terjadi dan ketidakseimbangan kehidupan sosial yang terkesan memberlakukan hukum rimba sangat terlihat jelas dan penindasan terhadpa kaum lema yang merajalela. Keadaan masyarakat arab pra-Islam yang demikian tersebut menjadi alasan kemunculan Islam untuk merubah dan membawa perubahan terhadap kehidupan dan sistem hukum yang ada di berbagai bidang guna mewujudakn kehidupan yang seimbang dan mengedepankan kemashlahatan di antara umat manusia.

\section{Hukum Islam sebagai Pembaruan}

Agama Islam datang sebagai pembawa perubahan. Al-Qur'an dan hadits nabi sebagai dua faktor utama dalam proses perubahan atau pembaruan yang dilakukan oleh agama Islam untuk mengatur norma dan juga kebiasaan masyarakat Jahiliyah. Al-Qur'an sendiri telah menjelaskan dengan tegas

${ }^{13}$ Ibid., 59. 
terkait penolakan dan kecaman terhadap perilaku Jahiliyah, seperti yang tertera dalam surat al-Maidah ayat 50 :

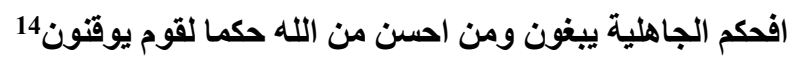

Ayat diatas menjelaskan kekuasaan Allah yang lebih kuat dan berkuasa dibanding dengan hukum Jahiliyah berlaku pada saat itu dan agama islam datang sebagai agama pembaruan yang merubah tatanan sitem hukum masyarakat Jahiliyah. Makna kata Jahiliyah yang terdapat dalam al-Qur'an dapat diartikan dalam beberapa makna yaitu zhan (sangkaan), hukm (hukum), Tabarruj (berhias/berperilaku), dan hamiyah (kesombongan).

Islam datang dengan pembaruan dalam bidang hukum keluarga. Hukum keluarga sendiri termasuk dalam sistem kekeluargaan dan sistem sosial yang diperbarui pada masa jahiliyah. Masalah-masalah yang terkait degan hukum keluarga telah mengalami perombakan secara bertahap atau berangsur-angsur, hal ini dibuktikan dengan adanya nash di bidang hukum keluarga yang masih bersifat patriarkal yang memang harus ditinjau dan dikaji secara mendalam terkait dengan perkembangan zaman dan demi menuju kemashlahatan.

Salah satu pembahasan yang dibahas dalam bidang keluarga ialah permasalahan nusyuz dalam rumah tangga. Nusyuz yang identik dengan pembangkangan atau tidak patuhnya antara suami atau isteri menjadi pembahasan tersendiri dalam konsep hukum keluarga. Dalam pembahasan terkait nusyuz dalam rumah tangga, terdapat pembahasan terkait penyelesaian dari nusyuz. Proses penyelesaian dari nusyuz tidak terlepas dari beberapa opsi atau pilihan langkah-langkah yang diambil dari seorang suami dalam rangka menyadarkan isteri dari sikap membangkang atau tidak patuh. ${ }^{15}$

Nusyuz merupakan pembahasan yang menyangkut hubungan antara suami dan isteri dimana salah satu dari mereka melakukan

\footnotetext{
${ }^{14}$ Al-Maidah (5): 50.
}

${ }^{15}$ Ali Yusuf as-Subkhi, Fiqh Keluarga, (Jakarta: Amzah, 2010), 302. 
kedurhakaan. Pembangkangan atau nusyuz bisa terjadi dari pihak suami mapun pihak istri, akan tetapi penyelesaian kedua nya memiliki perbedaan. watak perempuan yang dianggap berbeda dengan laki-laki menjadi penyebab adanya cara atau opsi penyelesaian atau penyembuhan dari nusyuz yang terjadi. Seorang suami diharapkan dapat mengetahui sebab terjadinya perubahan atau pembangkangan istri sehingga suami dapat menyelesaikan atau setidaknya dapat mengetahui penyebab terjadinya pembangkangan yang terjadi.

Al-Qur'an pun sudah menjelaskan beberapa opsi yang dapat digunakan oleh suami dalam penyelesaian nusyuz dalam rumah tangga, dalam al-Qur'an dijelaskan dalam surat an-Nisa ayat 34:

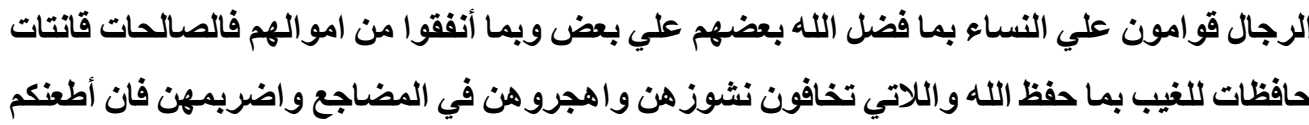
فلا تبغوا عليهن سبيلا إن الله عليا كبير

Ayat diatas menjelaskan tentang beberapa langkah penyelesaian atau opsi untuk seorang istri yang berpaling atau melakukan perbuatan yang durhaka. Beberapa opsi yang dapat digunakan oleh seorang suami ialah dari pemberian nasihat hingga memberikan hukuan fisik yang penjelasannya akan dijabarkan lebih lanjut pada pembahasan berikutnya.

Perlakuan terhadap istri terkait penyelesaian nusyuz ini jelas merupakan pembaruan yang dilakukan Islam, sebab apabila kita melihat kepada kondisi masyarakat arab yang pada saat itu sangat merendahkan derajat dan martabat perempuan jelas terdapat perbedaan yang signifikan perlakuan terhadap istri atau perempuan yang melakukan nusyuz terhadap suaminya. Karakter masyarakat arab pra-Islam yang cenderung patriarkhal menjadikan kedudukan laki-laki yang superior diatas perempuan dan perlakuan semena-mena terhadap perempuan. Islam sebagai agama pembaruan datang untuk membawa perubahan terhadap kebiasaan yang telah

\footnotetext{
${ }^{16}$ An-Nisa (3): 34.
} 
ada pada masyarakat Jahiliyah baik di bidang sosial, keluarga, maupun di bidang lainnya. ${ }^{17}$

\section{Konsep nusyuz dan proses penyelesaiannya}

Secara bahasa, nusyuz berasal dari kata nasyaza-yansyuzu-nusyuzan, yang memiliki arti meninggi, menonjol, durhaka, dan bertindak kasar. Sikap tidak patuh dari salah seorang diantara suami ataupun istri, atau perubahan sikap yang terjadi antara suami atau istri. Dalam pemakaiannya kata nusyuz ini kemudian berkembang menjadi al-ishyaan yang artinya durhaka atau tidak patuh. ${ }^{18}$

Secara terminologi, ulama Imam empat madzhab mendefinisak nusyuz dalam beberapa pengertian di antaranya:

- Ulama madzhab Hanafi mendefinisikan nusyuz dengan makna ketidaksenangan yang terjadi antara suami dan istri dimana salah satunya melakukan perbuatan yang tidak disukai baik bagi suami maupun istri.

- Ulama madzhab Maliki mendefinisikan makna nusyuz sebagai bentuk saling menganiaya antara pasangan suami dan istri.

- Menurut ulama madzhab Syafi'i makan nusyuz ialah perselisihan yang terjadi antara suami dan istri, dan

- Ulama madzhab Hambali mendefinisikan nusyuz sebagai bentuk ketidak senangan dari pihak suami atau istri yang disertai pergaulan yang tidak harmonis diantara keduanya.

Dalam Kompilasi Hukum Islam (KHI) dijelaskan makna nusyuz yaitu sebuah sikap istri yang tidak mau melaksanakan kewajibannya yaitu berbakti lahir dan batin kepada suami dan tidak mau melaksanakn kewajiban lainnya seperti melaksanakan dan mengatur keperluan rumah

17 Ira Lapidus, A History of Islamic Societies, Cet. X, (Cambrige: Cambrige University Press, 1995), 19-20.

18 Ahmad Warson Munawwir, al-Munawwir: Kamus Arab-Indonesia, (Yogyakarta: Pustaka Progresif, 1997), 1418-1419. 
tangga dengan baik. Hal ini dijelaskan dalam pasal 84 Kompilasi Hukum Islam ${ }^{19}$ :

1) Istri dapat dianggap nusyuz jika ia tidak mau malaksanakan kewajibankewajiban sebagaimana dimaksus dalam pasal 83 ayat (1) kecuali dengan alasan yang sah.

2) Selama istri dalam nusyuz, kewajiban suami terhadap istrinya tersebut pada pasal 80 ayat (4) huruf a dan b tidak berlaku kecuali hal-hal untuk kepentingan anaknya.

3) Kewajiban suami tesebut pada ayat (2) diatas berlaku kembali sesudah istri tidak melakukan nusyuz

4) Ketentuan tentang ada atau tidaknya nusyuz dari istri harus didasarkan atas alat dan bukti yang sah.

Dalam kompilasi hukum Islam sendiri hanya dibahas nusyuz bagi istri dan tidak ditemukan pembahasan dalam pasal lain yang mengatur atau menjelaskan tentang nuyuz bagi suami.

Perbuatan nusyuz dihukumi sebagai perbuatan yang diharamkan dalam syariat Islam. Syariat telah menetapkan hukuman bagi wanita atau istri yang melakukan nusyuz jika ia tidak mempan ketika diberikan nasihat oleh suami. Al-Qur'an telah menjelaskan beberapa langkah atau tindakan yang dapat dilakukan ketika seorang istri melakukan nusyuz terhadap suami. ${ }^{20}$

الرجال قوامون علي النساء بما فضل الله بعضهم علي بعض وبما أنفقوا من اموالهم فالصالحات قانتات حافظات للغيب بما حفظ الله و اللاتي تخافون نشوز هن واهجروهن في المضاجع واضربمهن فان أطعنكم فلا تبغوا عليهن سبيلا إن الله عليا كبير 21

Ayat diatas turun sebagai penjelas dan penentang bagi perilaku masyarakat Jahiliyah yang menganggap rendah derajat kaum perempuan dan

${ }^{19}$ Instruksi Presiden RI Nomor 1 Tahun 1991, Kompilasi Hukum Islam di Indosenia, Direktorat Jendral Pembinaan Kelembagaan Agama Islam Tahun 2000.

${ }^{20}$ Sayyid Sabiq, Fikih Sunnah 7, (Bandung: PT al-Ma'arif, 1999), 129.

${ }^{21}$ An-Nisa (3): 34. 
sebagai penolakan secara tegas terhadap sikap diskriminatif atau semenamena terhadap perempuan. Islam datang debagai penjelas dengan bekal berupa al-Qur'an dan hadits nabi memberikan pengetahuan untuk memerangi praktik Jahiliyah yang ada. Islam datang bukan hanya sebagai penentang dari setiap praktik Jahiliyah yang ada melainkan menawarkan norma yang pasti dan norma yang jelas yang dapat dianut untuk kelangsungan hidup yang lebih baik. $^{22}$

Ayat diatas menjelaskan tentang beberapa cara yang bisa untuk dilakukan dalam rangka penyelesaian nusyuz yang dilakukan oleh istri terhadap suami. Beberapa langkah atau opsi penyelesaiannya ialah sebagai berikut: ${ }^{23}$

Pertama, pemberian nasihat kepada istri dengan cara yang ma'ruf atau baik yang bertujuan untuk menyadarkan istri dari perbuatannya yang keliru. Menjelaskan dengan baik kepada istri terkait dengan dampak-dampak yang dapat ditimbulkan dari membangkangnya seorang istri, diantaranya bisa berupa keretakan dalam rumah tangga dan terlantarnya keluarga yang pada akhirnya dapat berakhirnya ke perceraian.

Kedua, ketika nasihat sudah diberikan masa pisah ranjang menjadi opsi kedua. Cara ini berfungsi sebagai hukuman psikologis bagi istri dan dalam kesendiriannya unutuk melakukan koreksi terhadap kekeliruannya. Maksud dari pisah ranjang disini ialah suami dan istri tidka tidur bersama, memalingkan tubuhnya dan tidka bersenggama dengannya. Jika istri mencintai suami maka hal tersebut akan dirasa berat olehnya dan diharapkan istri akan kembali sadar atas perbuatannya.

Ketiga, apabila kedua cara ini belum berhasil maka langkah selanjutnya yang dapat diambil ialah memberikan hukuman fisik kepada istri. Penting untuk dicatat, hukuman fisik berupa pukulan dalan rangka mendidik bukan

${ }^{22}$ Asghar Ali Enginer, Pembebasan Perempuan, (Yogyakarta: Lkis, 1999), 39.

${ }^{23}$ Ali Yusuf as-Subkhi, Fiqh Keluarga, (Jakarta: Amzah, 2010), 302. 
melakukan erhadpa istri dan pemukulan dilakukan di bagian yang tidak membahayakan istri dengan perlakuan secukupnya.

Opsi hukuman fisik yang dilakukan terhadap istri secara syara' tidka wajib dan tidka baik untuk dilakukan, hanya saja ini merupakan cara terakhir yang bisa dilakukan leh suami jika ia tidka mampu menundukkan istrinya yang telah melakukan nusyuz. Hal ini semata-mata untuk menyelamatkantabit keluarga dari kehancuran dan menyelamatkan rumah tangga dari kehancuran dan perpisahan. Perlu diingat hukuman fisik yang dilakukan tidaklah boleh sampai meninggalkan bekas luka, karena yang dimaksud dengan hukuman fisik disini ialah berupa penddidikan yang bertujuan untuk memperbaiki istri bukan yang lainnya.

Pelaksanaan opsi penyelesaian nusyuz ini hak mutlak seorang suami dan dilakukan secara pribadi bukan melaui wlai atau penguasa. Bahkan syariat menetapkan hal ini tanpa proses pengadilan, tanpa saksi atau bukti, sebab dalam hal ini syariat menaruh kepercayaan penuh terhadap suami untuk menjaga dan mendidik istrinya dengan baik demi mewujudkan keluarga yang harmonis dan menjunjung tingi syariat Islam. ${ }^{24}$

Syariat Islam tidak hanya menjelaskan atau mengatur nusyuz yang dilakukan oleh istri, tetapi Islam juga menjelaskan apa yang harus dilakukan jika seoarnag suami melakukan nusyuz terhadap istrinya. Allah menjelaskan dalam firmannya surat an-Nisa ayat 128:

وان امرأة خافت من بعلها نشوزا او إعراضا فلا جناح عليهما ان يصلحا بيذهما صلحا و الصلح خير واحضرت الانفس الشح وان تحسذوا وتتقوا فان الله كان بما تعملون خبير|25

Seorang suami dikatakan telah melakukan nusyuz apabila ia tidka melaksanan kewajibannya sebagai seorang suami terhadap istrinya, baik meninggalkan kewajibannya yang bersifat materi amupun materi, kewajiban fisik maupun psikis. Diantara kewajiban seoarng suami terhadpa istrinya ialah

\footnotetext{
${ }^{24}$ Mahmud al-Mashri, Perkawinan Idaman, (Jakarta: Qisthi Press, 2010), 360.

25 An-Nisa (4): 128.
} 
memperlakukan istrinya dengan cara yang baik (mu'asyarah bil ma'ruf) dan memberikan nafkah secara baik baik nafkah materi maupun non materi. Selain itu seorang suami dianggap nusyuz terhadap istrinya apabila ia melakukan perbatan kasar dan buruk seperti menyakiti fisik dan psikis istri, tidka melakukan hubungan badaniyah dalan kurun waktu tertentu dan tindakan lain yang bertentangan dengan pergaulan yang baik. ${ }^{26}$

Islam datang dengan membawa al-Qur'an dan nabi Muhammad sebagai rasul penyampai pesan dan ajaran agama telah merubah tatanan sosial dan paham yang berkembang di masyarakat Jahiliyah. Salah satu bidang yang diperbarui ialah pada bidang keluarga. Sebagai bukti pembaruan tersebut ialah ayat-ayat atau dalil-dalil yang menjelaskan tentang konsep nusyuz dan penyelesaiannya baik itu nusyuz yang dilakukan oleh istri maupun suami sehingga hal ini menjadi bukti bahwa Islam mencoba untuk merubah sistem patriarkhal yang diantu oleh masyarakat Jahiliyah terdahulu dan ketentuan yang dibuat tidaklah semena-mena dalam menyelesaikan masalah hubungan antara suami dan istri dalam keluarga, dimana Islam sudah mengatur ketentuan terkait antara keduanya dan tidak merendahkan derajat perempuan.

\section{Relevansi pembaruan Islam dengan proses penyelesaian nusyuz}

Salah satu ciri khas atau karakter yang diantu oleh masyarakat Jahiliyah terdahulu ialah kaum laki-laki yang memeang kekuasaan penuh terhadap suatu kaum dan mereka menganggap kaum perempuan merupakan kaum yang lemah dan cenderung melakukan perbuatan diskriminatif terhadap kaum wanita. Karakter patriarkhal yang sangat kuat melekat pada masyarakat Jahiliyah memberikan dampak buruk pada sistem sosial masyarakatnya. Perlakuan negatif terhadap pihak perempuan merupakan hal biasa yang dilakukan pada saat itu, wanita dianggap sebagai aib dalam sebuah keluarga

${ }^{26}$ Amir Syarifuddin, Hukum Perkwinan Islam di Indonesia: anatara Fiqh Munakahat dan Undnag-Undang Perkawinan, (Jakarta: Kencana, 2006), 193. 
dan tidak jarang pembunuhan dilakukan terhadap anak perempuan yang baru lahir karena mereka malu untuk mengakui apabila memiliki anak perempuan.

Al-Qur'an telah menjelaskan keadaan perempuan pada masa Jahiliyah seperti yang tertera dalam firman Allah surat al-Nahl ayat 58-59:

و إذا بشدر أحد هم بالأنثى ظل وجهه مسددا و هو كظيم (58) يتوارى من القوم من سدو

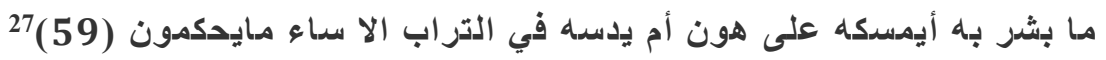

Ayat diatas menjelaskan tentang sikap masyarakt Jahiliyah ketika menanggapi kelahiran seornag anak perempuan. Mereka menganggap kelahiran anak perempuan merupakan sebuah aib dan menurunkan harga diri orang tua dan keluarga sehingga anak perempuan yang lahir tidak jarang untuk dibunuh atau dikubur hidup-hidup.

Agama Islam datnag sbegaia agama pembaruan merubah tatanan sosial pada masyarakat Jahiliyah dan menentang sistem hukum yang telah ada sebelumnya. Dalam al-Qur'an dijelaskan dan ditegaskan penolakan terhadap sistem hukum Jahiliyah.

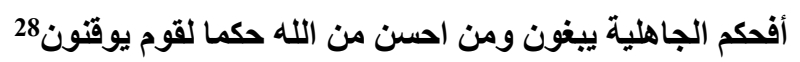

Ayat diatas menjelaskan penegasan tentang ketentuan Allah yang lebih baik dari hukum Jahiliyah yang berlaku saat itu dan Islam datang sebagai pembaruan yang merubah tatanan sistem hukum jahiliyah yang ada.

Islam datang dengan pembaruan dalam bidang hukum keluarga. Hukum keluarga sendiri termasuk dalam sistem kekeluargaan dan sistem sosial yang diperbarui pada masa jahiliyah. Salah satu pembahasan yang dibahas dalam bidang keluarga ialah permasalahan nusyuz dalam rumah tangga. Nusyuz yang identik dengan pembangkangan atau tidak patuhnya antara suami atau isteri menjadi pembahasan tersendiri dalam konsep hukum keluarga. Dalam pembahasan terkait nusyuz dalam rumah tangga, terdapat pembahasan terkait penyelesaian dari nusyuz. Proses

\footnotetext{
${ }^{27}$ Al-Nahl (16): 58-59.
}

${ }^{28}$ Al-Maidah (5): 50. 
penyelesaian dari nusyuz tidak terlepas dari beberapa opsi atau pilihan langkah-langkah yang diambil dari seorang suami dalam rangka menyadarkan isteri dari sikap membangkang atau tidak patuh.

Nusyuz merupakan pembahasan yang menyangkut hubungan antara suami dan isteri dimana salah satu dari mereka melakukan kedurhakaan. Pembangkangan atau nusyuz bisa terjadi dari pihak suami mapun pihak istri, akan tetapi penyelesaian kedua nya memiliki perbedaan. Watak perempuan yang dianggap berbeda dengan laki-laki menjadi penyebab adanya cara atau opsi penyelesaian atau penyembuhan dari nusyuz yang terjadi sebagaimana yang termuat dalam al-Qur'an surah an-Nisa': 34. Adapun solusi dan opsi yang ditawarkan adalah:

Pertama, pemberian nasihat kepada istri dengan cara yang ma'ruf atau baik yang bertujuan untuk menyadarkan istri dari perbuatannya yang keliru. Menjelaskan dengan baik kepada istri terkait dengan dampak-dampak yang dapat ditimbulkan dari membangkangnya seorang istri, diantaranya bisa berupa keretakan dalam rumah tangga dan terlantarnya keluarga yang pada akhirnya dapat berakhirnya ke perceraian.

Kedua, ketika nasihat sudah diberikan masa pisah ranjang menjadi opsi kedua. Cara ini berfungsi sebagai hukuman psikologis bagi istri dan dalam kesendiriannya unutuk melakukan koreksi terhadap kekeliruannya. Maksud dari pisah ranjang disini ialah suami dan istri tidka tidur bersama, memalingkan tubuhnya dan tidka bersenggama dengannya. Jika istri mencintai suami maka hal tersebut akan dirasa berat olehnya dan diharapkan istri akan kembali sadar atas perbuatannya.

Ketiga, apabila kedua cara ini belum berhasil maka langkah selanjutnya yang dapat diambil ialah memberikan hukuman fisik kepada istri. Penting untuk dicatat, hukuman fisik berupa pukulan dalan rangka mendidik bukan melakukan erhadpa istri dan pemukulan dilakukan di bagian yang tidak membahayakan istri dengan perlakuan secukupnya. 
Opsi hukuman fisik yang dilakukan terhadap istri secara syara' tidak wajib dan tidak baik untuk dilakukan, hanya saja ini merupakan cara terakhir yang bisa dilakukan leh suami jika ia tidka mampu menundukkan istrinya yang telah melakukan nusyuz. Hal ini semata-mata untuk menyelamatkantabit keluarga dari kehancuran dan menyelamatkan rumah tangga dari kehancuran dan perpisahan. Perlu diingat hukuman fisik yang dilakukan tidaklah boleh sampai meninggalkan bekas luka, karena yang dimaksud dengan hukuman fisik disini ialah berupa penddidikan yang bertujuan untuk memperbaiki istri bukan yang lainnya.

Proses penyelesaian dari perkara nusyuz yang dilakukan oleh istri ini sudah menunjukan perubahan yang dilakukan oleh Islam dalam rangka menghapus atau merubah sistem patriarkhal yang dianut oleh masyarakat jahiliyah dimana mereka menjadikan kaum laki-laki sebagai superior dan menindas kaum wanita. Proses penyelesaian perkara nusyuz yang ditawarkan Islam sangatlah menjunjung tinggi derajat perempuan dan menghargai keberadaan perempuan meskipun dlama hal ini mereka yang berbuat durhaka.

Hal tersebut dibuktikan dengan langkah-langkah yang harus diambil oleh seorang suami dalam menyelesaikan nusyuz yang dilakukan oleh istri, dari pengambilan langkah awal yaitu erupa nasihat sampai pada tahap terakhir apabila memang belum menemui jalan keluar dalma penyelesaian nusyuz seoarng suami dibolehkan untuk memukul istri, itupun dnegan ketentuan yang snagat ketat dimana pemukulan yang dilakukan tetap melihat pad kaidah dan dalam rangka pendidikan. Pemukulan yang dilakukan harus secara halus dan tidak meninggalkan bekas. Hal ini dilakukan dalam rangka mewujudkan kemashlahatan hubungan antara suami dan istri dan dalma rangka memperbaiki hubungan antara suami dan istri.

Syariat Islam tidak hanya menjelaskan atau mengatur nusyuz yang dilakukan oleh istri, tetapi Islam juga menjelaskan apa yang harus dilakukan jika seoarnag suami melakukan nusyuz terhadap istrinya. Seorang suami dikatakan telah melakukan nusyuz apabila ia tidak melaksanan kewajibannya 
sebagai seorang suami terhadap istrinya, baik meninggalkan kewajibannya yang bersifat materi amupun materi, kewajiban fisik maupun psikis. Diantara kewajiban seoarng suami terhadpa istrinya ialah memperlakukan istrinya dengan cara yang baik (mu'asyarah bil ma'ruf) dan memberikan nafkah secara baik baik nafkah materi maupun non materi. Selain itu seorang suami dianggap nusyuz terhadap istrinya apabila ia melakukan perbatan kasar dan buruk seperti menyakiti fisik dan psikis istri, tidka melakukan hubungan badaniyah dalan kurun waktu tertentu dan tindakan lain yang bertentangan dengan pergaulan yang baik. ${ }^{29}$

Masayarakat Jahiliyah yang memang pada masa dahulu hidup dalam kegelapan dan jauh dari aturan memiliki karakter yang mencolok yaitu karakter patriarkhal, dimana mereka menjunjung tinggi kedudukan laki-laki diatas perempuan dan menjadikan laki-laki sebagi superior dalam kehidupan bermasyarakat. Tindakan-tindakan diskriminatif dan merendahkan derajat perempuan merupakan hal yang biasa dan lumrah di kalangan mereka. Hal tersebut merupakan salah satu karakter dan kebiasaan yang ditentang oleh agama Islam yang daang sebagai agama pembaruan dan membawa perubahan

Islam datang membawa perubahan di berbagai aspek kehidupan masyarakat arab pra Islam atau yang dikenal dengan masyarakat Jahiliyah. Perubahan mencakup bebrapa aspek seperti pemerintahan, ekonomi, sistem sosial hingga perubahan dalam bidang keluarga. Salah satu pembaruan yang dibawa Islam dalam bidang keluarga ialah perubahan karakter patriarkal yang telah mendarah daging.

Konsep nusyuz yang diatur dalam Agama Islam merupakan salah satu bentuk pembaruan dan perubahan ke arah yang lebih baik dalam bidang keluarga, dimana Islan memperlakukan perempuan lebih baik dan mengangkat derajat perempuan untuk bisa mendapat hak yang sama dimata hukum. Hal ini dibuktikan dengan ketentuan syariat Islam yang mengatur

${ }^{29}$ Amir Syarifuddin, Hukum Perkwinan Islam di Indonesia: anatara Fiqh Munakahat dan Undang-Undang Perkawinan, (Jakarta: Kencana, 2006), 193. 
tentang cara penyelesain nusyuz yang dilakukan oleh istri terhadap suami. Terdapat langkah-langkah yang harus ditempuh sebagai bentuk menghargai kaum wanita dan menjungjung tinggi martabat wanita. Cara yang ditawarkan merupakan langkah preventif guna mencegah hal yang tidak diinginkan dalam sebuah rumah tangga berupa kehancuran atau perpisahan yang bisa terjadi dalam sebuah keluarga, pemberian nasihat hingga hukuman fisik sesuai ketentuan yang berlaku dapat digunakna oleh seorang suami dalam menyelesaikan masalah atau menyadarkan istri yang telah melakukan pembangkangan terhadap suami.

Selain itu Islam tidak hanya mengatur ketentuan nusyuz terkait aturan terhadap istri saja, melainkan Islam juga mengatur ketentuan bagaimana sikap yang harus dilakukan jika seorang suami melaukan nusyuz dalam sebuah keluarga. Islam telah datang sebagai agama pembaruan yang menjunjung tinggi martabat perempuan dalam rangka menghapuskan sistem patriarkal yang dianut masyarakat Jahiliyah terdahulu.

\section{Penutup}

Islam merupakan agama yang yang dibawa Nabi Saw. sebagai jawaban atas problematika di masa jahiliyah. Perbedaan budaya dan sistem kehidupan pada masa Jahiliyah dan era kenabian memberikan pengaruh pada tatanan struktur keislaman. Adanya hukum sebagai obyek pijakan tentu harus memberikan jawaban yang progresif dan tidak memihak. Hal inlah yang mengundang suatu pembaruan dalam Islam. Salah satu pembaruan yang dilakukan oleh agama Islam ialah pembaruan di bidang hukum keluarga. Hukum keluarga sendiri termasuk dalam sistem kekeluargaan dan sistem sosial yang diperbarui pada masa jahiliyah. Masalah-masalah yang terkait dengan hukum keluarga telah mengalami perombakan secara bertahap atau berangsur-angsur, hal ini dibuktikan dengan adanya nash di bidang hukum keluarga yang masih bersifat patriarkal yang memang harus ditinjau dan dikaji secara 
mendalam terkait dengan perkembangan zaman dan demi menuju kemaslahatan.

Salah satu pembahasan yang dibahas dalam bidang keluarga ialah permasalahan nusyuz dalam rumah tangga. Nusyuz yang identik dengan pembangkangan atau tidak patuhnya antara suami atau isteri menjadi pembahasan tersendiri dalam konsep hukum keluarga. Berkaitan dengan nusyuz dalam rumah tangga, al-qur'an sebagai sumber rujukan utama menawarkan beberapa dalam mneyelesaikannya, antara lain: Pertama, pemberian nasihat kepada istri dengan cara yang ma'ruf atau baik yang bertujuan untuk menyadarkan istri dari perbuatannya yang keliru. Kedua, sebagai hukuman psikologis bagi istri dan dalam kesendiriannya unutuk melakukan koreksi terhadap kekeliruannya. Ketiga, memberikan hukuman fisik kepada istri.

\section{DAFTAR PUSTAKA}

Abdul Karim, Muhammad, Sejarah Pemikiran dan Peradaban Islam, Cet. VI, Yogyakarta: Bagasakara, 2015

Ali dan Zuhdi, Ahmad, Kamus Kontemporer, Yogya: Yayasan Ali Maksum, 1996

Ali Enginer, Asghar, Pembebasan Perempuan, Yogyakarta: Lkis, 1999

al-Mashri, Mahmud, Perkawinan Idaman, Jakarta: Qisthi Press, 2010

Bashier, Zakaria, The Makkan Crucible, Licester: Islamic Foundation, 1978

Hasan, Masudul, History of Islam, Vol. 1, India: Adam Published, 1995

Ibrahim Hasan, Hasan, Tarikh al- Islam, Vol. 1, Beirut: Dar al- Jayl, 1996 
Instruksi Presiden RI Nomor 1 Tahun 1991, Kompilasi Hukum Islam di Indosenia, Direktorat Jendral Pembinaan Kelembagaan Agama Islam Tahun 2000

Jawad, Haifa, The Right of Women in Islam; An Authentic Approach, Cet I, New York: S.T. Martin's Press, 1989

Kurnia Yahya, Yuangga, "Pengaruh Penyebaran Islam di Timur Tengah dan Afrika Utara: Studi Geobdaya dan Geopolitik", dalam Jurnal al-Tsaqafa, Vol. 16, No. 1, .2019

Lapidus, Ira, A History of Islamic Societies, Cet. X, Cambrige: Cambrige University Press, 1995

Nasution, Khoiruddin "Islam Membangun Masyarakat Bilateral dan Implikasinya terhadap Hukum Keluarga Islam Indonesia”, dalam Jurnal al-Mawarid, Edisi xvii, 2007

Sabiq, Sayyid, Fikih Sunnah 7, Bandung: PT al-Ma'arif, 1999

Supriyadi, Dedi, Sejarah Peradaan Islam, cet. VIII, Bandung: Pustaka Setia, 2016

Syarifuddin, Amir, Hukum Perkwinan Islam di Indonesia: anatara Fiqh Munakahat dan Undnag-Undang Perkawinan, Jakarta: Kencana, 2006

Warson Munawwir, Ahmad, al-Munawwir: Kamus Arab-Indonesia, Yogyakarta: Pustaka Progresif, 1997

Yusuf as-Subki, Ali, Fiqh Keluarga, Jakarta: Amzah, 2010 